\title{
Going beyond "briefing": a product design approach to the life cycle
}

\author{
Eduardo Romeiro Filho, Aline Capanema de Barros \\ Universidade Federal de Minas Gerais \\ e-mail: romeiro@dep.ufmg.br
}

\begin{abstract}
This research provides a contribution to the debate about the need for greater interaction between the product development team and users, spread over the life cycle of industrial products. The activities related to design and product development emerged from a production model that favors large-scale production and is focused on the catering for previously identified and mapped needs (often by marketing) in a product "briefing". However, this model seems depleted mainly because of new concepts such as Simultaneous Engineering, use of CAE/CAD/CAM technologies and other changes that have happened especially since the 1990s and have brought a remarkable intensification of competition between companies.
\end{abstract}

Keywords: product design, life cycle assessment, product development.

\section{Introduction}

It is often said that the main goal of a capitalist enterprise is to generate dividends for its shareholders. In these cases, the main demand to be met, within a traditional capitalist logic, is maximizing profits. This approach is, however, the second of Deming's "seven fatal diseases" (WALTON, 1989): emphasis on short-term profits (it is important to highlight the administration's excessive concern with short-term figures and profits at the expense of a commitment to the company's future. They act as shareholders, not as entrepreneurs). In many cases, the greatest concern of designers is the company's interest instead of the consumers'. Examples such as the design of urban buses in Brazil (ROMEIRO FILHO, 1999) illustrate this situation (one could argue - based on the criteria above - that the bus manufacturers' clients are the public transport companies, not the population that actually uses the buses).

The user (who interacts with the final product) is considered to be a client of the company, not of the design team. This point of view is (obviously) limited, but it is a fairly common approach since it is easier for those involved (designers and managers) to treat the product's users as objects that are voiceless and passive when it comes to the development of design solutions. Interpreting the wishes of the costumer (or "buyer") is seen as a task specific to the marketing department, which often works separately and independently from the product development area of the company. In fact, several authors, such as Slack et al. (2002), make distinctions between the main functions of an organization. They are 1) production, 2) marketing, 3) accounting and finance and 4) product/ service development. Rozenfeld et al. (2006, p. 11) treat this situation as "traditional". PMI (PROJECT..., 2004) also lists the most common design features and structures in companies (classified as functional, matrix and projectized). In the case of organizations that are dedicated to routine, and not to project, the prevalence of functional structures is observed. Nevertheless, the problems resulting from the "departmentalization" of industrial enterprises are persistent.

The advent of Concurrent Engineering principles brought up much criticism regarding this separation of functions in a company. Those were first described in the work of Womack et al. (1994).

Based on this situation, this paper presents some reflections on the work of designers and others involved in product development. The classical approach to the designer's activity as an instrument of mass production and of the organization requires the existence of a "briefing". In a company with a bureaucratic point of view, together with a clear division of power (CHIAVENATO, 2003), the application of a "briefing", created by the senior management and the marketing department, can be considered absolutely appropriate. That is because its application includes elements of legal nature, standardization, formal communication, division of labor, technical competence and merit, among others. "Briefing" is (quite simply) a list of issues to be handled by the designer in product development, bearing in mind the client's needs. According to Philips (2008), it consists of some basic topics such as 1) the nature and context of the project, 2) industry analysis, 3) consumer market, 4) the company's portfolio, 5) business objectives and design strategy, 6) goal, deadline and budget of the project, 7) research and information, 8) appendix. 


\section{A contemporary approach to the development of products}

The design methodology previously described does not consider the users as elements of discussion and as capable of expressing their own needs. This makes the briefing the only basic source of information for the product development team. One might assume that if this document (briefing) is properly prepared, the project will be carried out successfully. However, if the multiple variables of the project are taken into account, it may behave as if struck by the "Butterfly effect" described by Lorenz (GLEICK, 1989). While studying the climate in 1963, Edward Lorenz built a mathematical model of how the air moves in the atmosphere. He came to the conclusion that small variations in initial values of variables in his model (like the swinging of a butterfly wing) would lead to widely varying results in the system (like an unexpected storm).

Although this comparison may seem exaggerated, it is clear that small dysfunctions early in the project will lead to completely different results in the final product. In this case, the "briefing" acts as a set of utterances that determine the progress of the product design. Nonetheless, the process of product design is dynamic and should constantly receive new information and evaluation results. This way, the partial results would be monitored and controlled during the process. Despite that, the "briefing" does not require this process. It actually involves a careful definition of product requirements early in the project, which reduces the user involvement to the early stages of product development such as requirements definition and market research.

This model leaves room for a great amount of criticism and should not be regarded as the most appropriate one, especially when confronted with principles such as Concurrent Engineering (ROMEIRO FILHO et al., 2010). Over time new grounds have been added to the relationship between the designer and the user, aiming the inclusion of more suitable features for different products. In spite of the fact that the design is currently seeking tools that provide greater interaction between users and designers, the adoption of participatory methodologies is still very limited (even a long time after studies such as the one from BUCCIARELLI, 1994). Some of these tools arise in areas where the design activity is more recent, as is the case of user-centered design proposal in the software development area (BEVAN, 2004; CARROL et al., 2002).

\section{The inclusion of new customers}

The production model adopted by developed countries since the industrial revolution gradually separated those involved in the production process. In cases when the Taylorist and Fordist models of production were adopted, some of them were eliminated or had their role in the process reduced. This situation, though partially justified when facing the complexity of industrial companies, reaches a limit when meeting the wishes of consumers, especially as seen in the 1990's. The arrival of new global "players" (like China), associated with the effects of the crisis that reached the developed economies in 2008 created an interesting scenario in which changes in terms of demand for new products and addressing the needs of new consumers become the focus for most of the companies.

The inclusion of new "customers" for the product comes as a consequence to this scenario. The marketing department of companies sees the clients as users or consumers of the final product. This approach represents an important change over the previous one (centered on the company's profits), as it considers that the product must first meet the consumer's needs before the company's (or its stakeholders). Furthermore, this integration, far from opposing the previous situation represents an evolution and sophistication of the current system of capitalist production. Since the 1970's (in rich countries) the market of consumer goods is no longer focused on expanding. It now aims to the replacement for goods with better characteristics and higher quality. The quality is, instead of the price, the main attraction of industrial products (about this evolution, see Figure 1).

In these cases, the consumer becomes the central focus of the product development team that uses several tools of marketing and market research. There is not, however, an actual involvement of consumers in the product development. What happens is a relationship where the marketing department acts as an observer and, sometimes, stimulates the client (in a subject-object relationship) who has his or hers habits and desires analyzed and processed into products.

Seeing the consumer as a client enables an analogy with the language of quality. Juran (1992) indicates as "clients" all those affected by the product, differentiating internal and external clients, as people inside and outside the company, respectively. According to the author, although the users

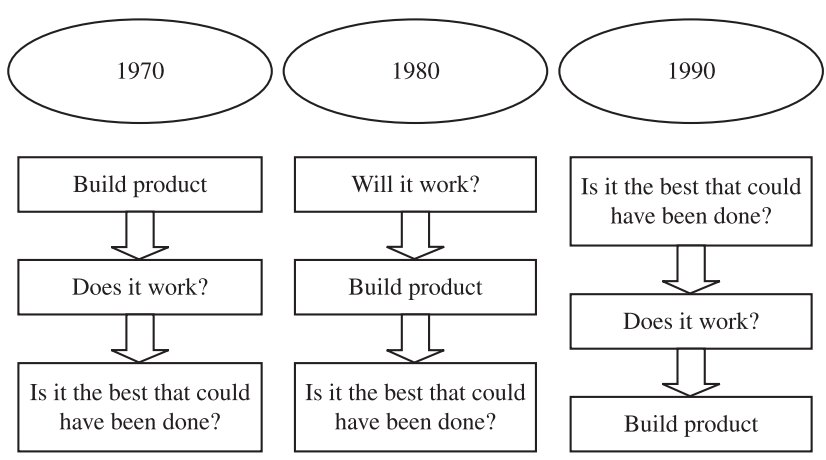

Figure 1. Evolution of the design process from 1970 to 1990. (BOSSAK, 1998 apud NITSCHE, 2004) 
(or final clients) are the most important group, they are far from being the only one. It would be interesting to extrapolate the concept stated by Juran and consider all those customers involved with the product throughout its life cycle.

In this way, the buyer will be the final customer, together with his or her spouses, children and other family members. An interesting example lies in the decision to purchase a car: the decision criteria for purchasing requirements incorporate not only the traditional buyer ("head of household"), but the whole family group. It takes into account aspects such as access for the elderly, child safety, maneuvering, large internal space etc. When buying a car, the clients will also consider factors that relate to others than them, like maintenance costs (many people choose the car after a mechanic they trust indicates it), salvage value, etc. It becomes clear that the concept of client incorporates other social groups beyond the direct buyers and users (ultimately, the design of wagons that absorb impact in case of trampling aims to meet the requirements of pedestrian safety).

The needs of other groups should be taken into consideration. These groups can be of workers who assemble the product (Boothroyd, Dewhurst and Knight (2002) consider this the basic principle for the implementation of DFMA Design for Manufacturing and Assembly), or extract the raw material needed, people who live close to factories and are affected by the emission of effluents, those involved in product's maintenance and disposal etc. Finally, one may evaluate a product analyzing the impacts that it causes to the environment in which it is inserted. Although this is an interesting approach to product design, it is also highly complex due to the variability inherent to a dynamic environment.

\section{New methodological approaches}

In this scenario, new approaches that go beyond the traditional briefing are required. It is necessary to adopt methodologies that privilege the use of participatory principles, in which the relationship between designers and clients is changed - the designer should allow the client to effectively participate on the definition of concepts related to the product. Furthermore, the client should be seen as a source of information that is relevant to the excellence of the product and included to the development process.

There are several tools available to enable this integration. Interviews, focus groups and other tools of marketing research (MALHOTRA, 2001), participatory research (such as action research, described by Thiollent (2007)) and analysis of the activity using an ergonomic approach (as proposed by Guérin (1991)) can contribute to a more complete approach of activities related the product. Of course it is not a free or fast implementation, and it is not only by applying these research tools that one will guarantee the necessary changes in the overall project approach. When analyzing the product's life cycle it is possible to see that it will present different interactions (and interventions) between numerous social groups with distinctive characteristics, goals, expertise and interests on the product. Thus, the challenge is indeed the inclusion of other groups besides the end users of the product.

Figure 2 (adapted from ROMEIRO FILHO et al., 2010) shows in a simplified way some groups that are related to the different stages of the life cycle of industrial products. Together with those, other groups may also be added to this life cycle, for example, people who live close to the factories and have an indirect, but relevant, relationship with their production processes and possible effluents.

Understanding and recognizing these relationships is of utter importance in order to the product to meet the proposed specifications. These specifications are increasingly broad and should not be considered only as an extended briefing. They should be constantly updated so that the project is conducted properly. The problem lies in identifying the needs of each group and each stage of the life cycle.

\section{Implementation examples}

The following are cases of application of the concepts proposed above, taken from surveys conducted in Brazil. Of course, the approach should be focused on aspects considered relevant for each project. This relevance can be demonstrated by the application of tools such as LCA Life Cycle Analysis (CHEHEBE, 1998; HOCHSCHORNER; FINNVEDEN, 2003), which can demonstrate where and in which situations the interaction product - user is critical or

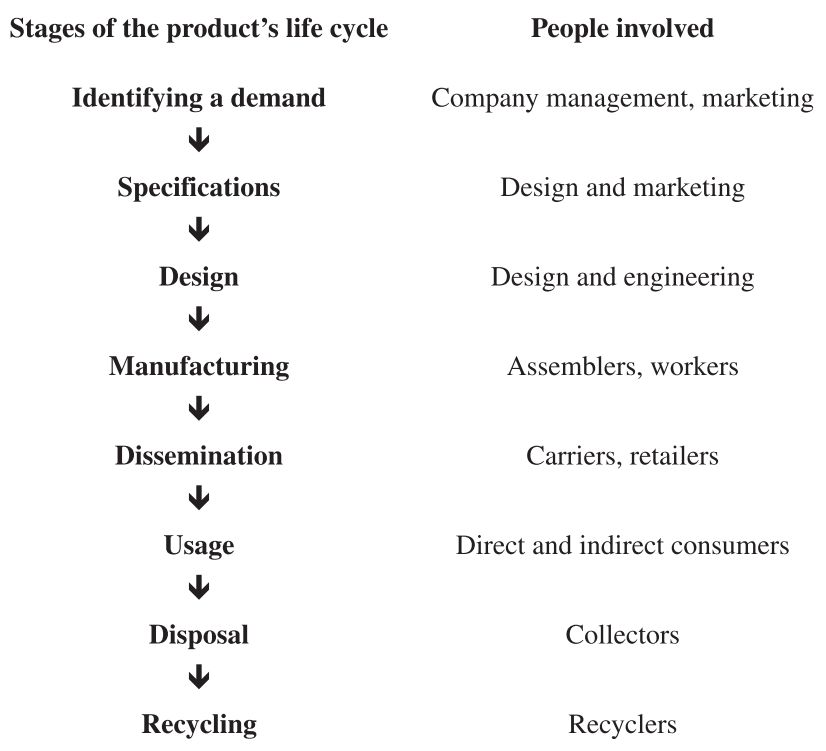

Figure 2. Groups involved in every step of the product's lifecycle. (adapted from ROMEIRO FILHO et al., 2010). 
ought to be improved. LCA should, however, be associated with other research tools such as those mentioned in the previous section.

\subsection{PET bottles}

The first example, taken from Romeiro Filho and Lima (2008) consists of the application of EWA - Ergonomics Work Analysis (GUÉRIN, 1991) to recyclers of PET bottles. The study showed that a feature set in project (the adoption of a "security ring" double lock - Figure 3, left - in the screw cap) would eventually affect the manual recycling, as it hindered the separation of the different plastic materials present in the bottle (PET-polyethylene terephthalate) and in the security ring (HDPE - high density polyethylene), a mandatory requirement when it comes to selling the material to recycling companies. In this case, the EWA was used in an association of collectors and pointed out the difficulties in a real work situation.

As a second stage of the study, the results of EWA were presented to designers responsible for the project of PET bottles who had no knowledge of the relationship between their design decisions (determined by the need to guarantee the inviolability of the pack) and problems arising in the process of manual recycling. In this case, the simple adoption of a "win lock" system (Figure 3, right) would help to solve the issue.

\subsection{Agricultural equipment}

The EWA was also used for analyzing the use of agricultural equipment such as an animal traction planter (ROMEIRO FILHO, 2012) and demonstrated how climatic and cultural aspects can influence the actual conditions of usage of the equipment. In this case, the problem for the designers was indeed the lack of knowledge about the real conditions of use of the equipment in the country, which has very significant differences between cultures, weather conditions, levels of technical knowledge of farmers etc. When such information was incorporated, the design of the machinery suffered several changes that lead to the improvement of the conditions of use (Figure 4). Some examples of these changes are use of longer handlebars, changes in the dimensioning of containers and simultaneous use of two lines to increase the stability of the device.

\subsection{Packaging}

Concepts of design methodology and LCA were applied to examine the life cycle of a series of typical food products from small farmers in order to develop new packaging that would increase the estimated value associated to this type of product (MIRANDA; ROMEIRO FILHO, 2008; ROMEIRO FILHO; VILELA, 2007). The research, using focus groups and individual interviews, reckoned that consumers had strong cultural references regarding the products such as elements linked to tradition, rural life and

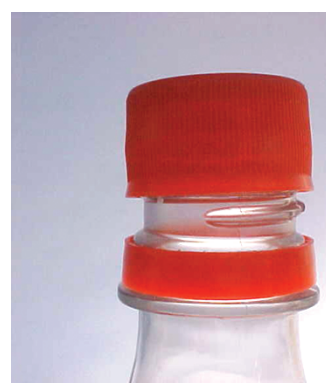

Double Lock ring

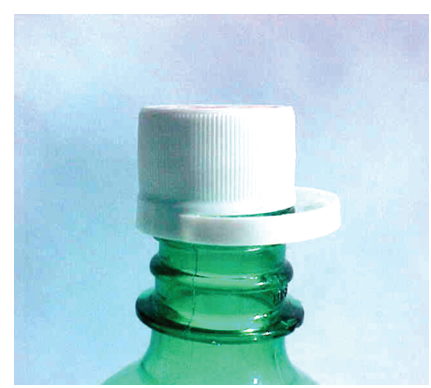

Win Lock ring
Figure 3. Different options of safety rings in PET bottles.
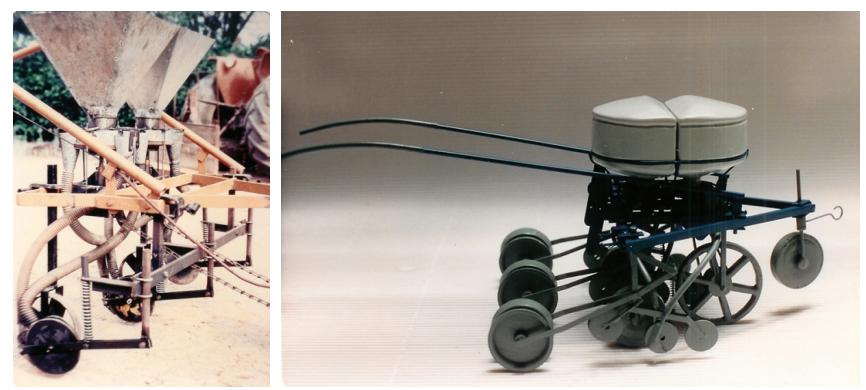

Figure 4. Planter before and after the redesign.

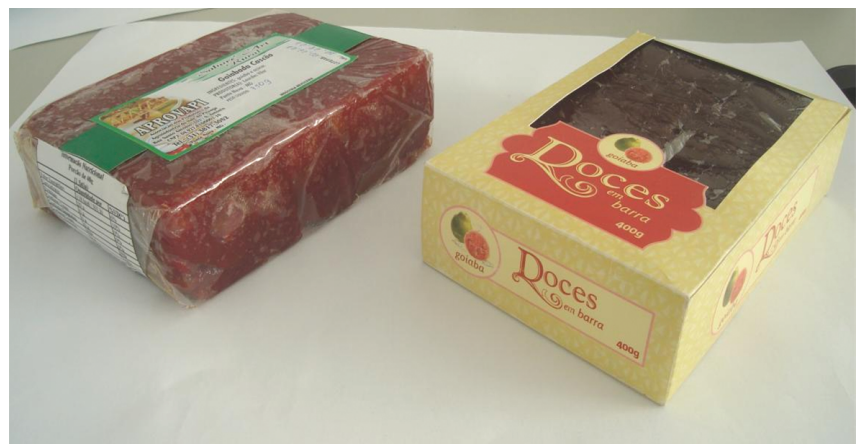

Figure 5. Packaging for homemade sweets, before and after intervention.

family which were not used in the design of the packaging. Thus, the application of elements of the cultural background of consumers (for example, images related to rural and traditional, and historical references, as in Figure 5) was responsible for a significant increase in sales and in profits for producers.

\section{Conclusions}

The use of different research tools serves as a basis for the diagnosis of the real interaction with the product, throughout its life cycle (Figure 2). Therefore, several "clients" related to the product may be included so that the excellence of the developed solution can be easily achieved using a systemic approach and solutions that consistently meet the needs and selection criteria spread 
through the various stages of the products' life cycle. The problem in this case happens to be how to manage the vast amount of information gathered, which will require the adoption of efficient information management for the company. However, it is believed that the main issue is not only the adoption of contemporary technology tools (such as PLM - Product Lifecycle Management Systems, for example), but the appropriate structuring of the product development process to include a broader universe of actors (customers, users, etc...), ensuring better results for the product and the company in long term.

\section{References}

BEVAN, N. Usability net methods for user centered design. London: Serco Usability Services, 2004.

BOOTHROYD, G.; DEWHURST, P.; KNIGHT, W. Product design for manufacture and assembly. New York: Marcel Dekker, 2002. p. 1-41.

BOSSAK, M. A. Simulation based design. Journal of Materials Processing Technology, v. 76, p. 8-11, 1998. http://dx.doi.org/10.1016/S0924-0136(97)00308-7

BUCCIARELLI, L. L. Designing Engineers (Inside Technology). Cambridge: MIT Press, 1994.

CARROL, C. et al. Involving users in the design and usability evaluation of a clinical decision support system. Computer Methods and Programs in Biomedicine, Elsevier Science Ltd., 2002.

CHEHEBE, J. R. B. Análise do ciclo de vida de produtos: Rio de Janeiro: Qualitymark, 1998. 104 p.

CHIAVENATO, I. Introdução à teoria geral da administração: uma visão abrangente da moderna administração das organizações. rev. atual. Rio de Janeiro: Elsevier, 2003.

GLEICK, J. Caos - a criação de uma nova ciência. Rio de Janeiro: Editora Campus, 1989.

GUÉRIN, F. et al. Comprende le travail pour le transformer. Paris: Éditions de l'ANACT, 1991.

HOCHSCHORNER, E.; FINNVEDEN, G. LCA Methodology: Evaluation of two simplified life cycle assessment methods. The International Journal of Life Cycle Assessment, v. 8, n. 3, p. 119-128, 2003.

JURAN, J. M. A qualidade desde o projeto: os novos passos para o planejamento da qualidade em produtos e serviços. São Paulo: Thomson Pioneira, 1992

MALHOTRA, N. Pesquisa de Marketing - uma orientação aplicada. 3. ed. Porto Alegre: Bookman, 2001.719 p.
MIRANDA, C. A. S.; ROMEIRO FILHO, E. Desenvolvimento de embalagens para produtos alimentícios típicos: um desafio metodológico. In: ENCONTRO NACIONAL DE ENGNHARIA DE PRODUÇÃO, 28., 2008, Rio de Janeiro. Anais... Rio de Janeiro: ABEPRO, 2008. v. 1, p. 1-10.

NITSCHE, A. T. Utilizando o processo de desenvolvimento de produtos para melhorar o processo de transferência de tecnologia. 2004. Dissertação (Mestrado em Engenharia de Produção)-Universidade Federal de Minas Gerais, Belo Horizonte, 2004.

PHILIPS, P. Briefing: a gestão do projeto de design. São Paulo: Editora Blucher, 2008.

PROJECT MANAGEMENT INSTITUTE - PMI. PMBoK: Um guia do conjunto de conhecimentos do Gerenciamento de Projetos. 3. ed. Pennsylvania: Project Management Institute, 2004.

ROMEIRO FILHO, E. Enfoque ergonômico do ônibus urbano no Brasil: Exemplo de Belo Horizonte. In: CONGRESSO LATINO-AMERICANO DE ERGONOMIA, 5.; CONGRESSO BRASILEIRO DE ERGONOMIA, 9., 1999, Salvador. Anais... Salvador: ABERGO, 1999.

ROMEIRO FILHO, E. Uma Abordagem Centrada no Usuário para o Projeto de Máquinas Agrícolas de Tração Animal. Gestão \& Produção, v. 19, p. 93-102, 2012.

ROMEIRo FILHO, E. et al. Projeto do Produto. Rio de Janeiro: Elsevier Editora, 2010.

ROMEIRO FILHO, E.; LIMA, R. M. R. A contribuição da análise ergonômica ao projeto do produto voltado para a reciclagem. In: PIMENTA, H. C. D.; GOUVINHAS, R. P. (Orgs.). Ferramentas de Gestão Ambiental para competitividade e sustentabilidade. Natal: Editora do CEFET-RN, 2008. v. 1, p. 110-135.

ROMEIRO FILHO, E.; VILELA, N. C. Utilização de pesquisa qualitativa para geração do conceito de embalagens para biscoitos artesanais de São Tiago - MG. In: ABREU, J. C. (Org.). Cooperativismo Popular e Redes Solidárias. São Paulo: All Print Editora, 2007. v. 1, p. 156-168.

ROZENFELD, H. et. al. Gestão de desenvolvimento de produtos. São Paulo: Editora Saraiva, 2006.

SLACK, N. et al. Administração da Produção. São Paulo: Editora Atlas, 2002.

THIOLLENT, M. Metodologia da pesquisa-ação. 15. ed. São Paulo: Cortez, 2007.

WAlton, M. O Método Deming de Administração. Tradução de José Ricardo Brandão Azevedo. Rio de Janeiro: Marques-Saraiva Gráficos e Editores S.A., 1989.

WOMACK, J. P. et al. A Máquina que Mudou o Mundo. 4. reed. Rio de Janeiro: Editora Campus, 1994. 